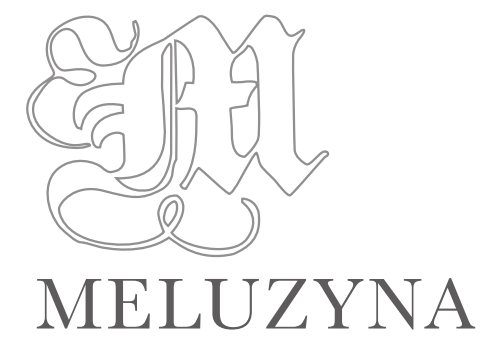

ISSN 2449-7339

2 (5) (2016) I Rocznik III

DOI: 10.18276/me.2016.2-02

PRZEKROJE I ZBLIŻENIA

\author{
Joanna Woron-Trojanowska \\ Uniwersytet Łódzki
}

\title{
Topos quinque gradus amoris w polskim romansie barokowym
}

W świecie bohaterów romansów bardzo istotną sprawą jest to, że są oni, co nie zaskakuje, uczestnikami historii miłosnych. Teresa Michałowska podkreśla, że na los postaci bezpośredni wpływ mają dwa bóstwa: Fortuna i Wenera (Michałowska, 1972, s. 483), bohater jest im całkowicie podporządkowany. Francuski teoretyk Pierre-Daniel Huet w rozprawie definiującej romans Traité de l'origine des romans (1670) jako istotny wyznacznik gatunku przedstawił tematykę miłosną (Miszalska, 2003, s. 90) ${ }^{1}$. Huet wziął w obronę romans, podkreślając przy tym potrzebę tworzenia umoralniających treści o głębokim uczuciu (Kruszewska, 1960, s. 61). Poeci chętnie sięgali do repertuaru topiki miłosnej charakterystycznej dla omawianego gatunku². Topos pięciu stopni miłości miał szereg wybitnych realizacji w poezji lirycznej i warto sprawdzić, jak funkcjonuje w gatunku, w którym miłości ulegają protagoniści i staje się ona przyczynkiem do rozwoju fabuły. Analiza tytułowego toposu zostanie dokonana na przykładzie utworów Hieronima Morsztyna ${ }^{3}$, Wacława Potockiego (Potocki, 1924a), Adama Korczyńskiego (Korczyński, 2000) oraz Elżbiety Drużbackiej

\footnotetext{
e-mail autorki: joanna.woron@wp.pl

1 Rozprawa Hueta to jedyne całościowe siedemnastowieczne omówienie gatunku (Miszalska, 2003, s. 89).

2 Topika stanowiła dla twórców romansów źródło elementów niezbędnych do stworzenia postaci w zgodzie ze standardami obowiązującymi w danym gatunku. Większość toposów występujących w polskim romansie barokowym omówiła Teresa Michałowska. Obok quinque gradus amoris do popularnych topoi miłosnych należą między innymi: przedstawianie miłości jako choroby, deklaracja miłości, broczenie krwią z miłości czy tęsknota miłosna (zob. Michałowska, 1972, s. 478-479).

3 Zbiory Filomachija oraz Antypasty małżeńskie (na Antypasty składają się przypisywana Morsztynowi Banialuka oraz dwa prozaiczne teksty o niepotwierdzonym autorstwie: o Galezyjusie i Filidzie oraz Przemysławie i Cecylii): Alfonsa, książęcia ateńskiego, i Orystelle, królewny kreteńskiej, miłość śmiercią okrutna zapieczętowana; Historyja barzo piękna o Talezie, królewicu lidyjskim, a o Perepodzie, królewnie aragońskiej; Żałosny koniec miłości niezbednej dwojga ludzi w sobie się kochających; Historyja ucieszna o zacnej królewnie Banialuce ze wschodniej krainy; Druga historyja. O Galezyjusie, synu Demokryta, i Filidzie, córce Arystydesa, szlachty cypryjskiego króla; Trzecia historyja. O Przemysławie, książęciu oświęcimskim, i o Cecylijej, małżonki jego, dziwnej stateczności.

4 Fabuła o ksią̇ęciu Adolfie dziedzicu Roksolanii, którego Czas, przez lat trzysta szukając, znaleźć nie mógł. Przypadkiem powracając z wyspy szczęśliwości, od tegoż Czasu złapany, śmierci prawu zadosyć uczynić musiał, które dla wszystkich najdłużej żyjących ludzi postanowione. Poetka, choć tworzyła już w czasach oświecenia, uważana jest za przedstawicielkę późnej fazy baroku: „Elementy rokokowe, arkadyjskie, sporadycznie klasycystyczne, owe przejawy wstępnej, prekursorskiej fazy oświecenia wzbogacają dominującą w jej dokonaniach artystycznych konwencję barokową" (Stasiewicz, 1992, s. 138).
} 
Lionel Friedman uważa, że źródła quinque gradus amoris sięgają IV-III wieku p.n.e. ${ }^{5}$ Zaznacza, że błędnie uznawano „points de la litterature amoureuse” za średniowieczny wytwór, początkowo obejmujący cztery elementy, które następnie scholastycy rozszerzyli do pięciú ${ }^{6}$. W Ars amatoria Owidiusza, choć mowa jest o etapach miłości, autor ich jednak nie wymienia i nie hierarchizuje (Hanusiewicz, 2004, s. 33). W swoich komentarzach do twórczości starożytnych poetów topos ów umieścili Aelius Donatus (komentarz do Eunucha Terencjusza) i Porfiriusz (komentarz do Pieśni Horacego) (Curtius, 2009, s. 540). Ernst Robert Curtius zauważa, że przeniknął on z poezji łacińskiej do twórczości romansowej powstającej w językach narodowych (Curtius, 2009, s. 542). Jean Lemaire de Belges, jeden z francuskich Wielkich Retorów, pisał:

Wielcy poeci mówią, że pięć linii jest w miłości, to znaczy pięć punktów czy też pięć stopni szczególnych, a więc: spojrzenie, rozmowa, dotknięcie, pocałunek i ostatnie, co jest najbardziej pożądane i do którego wszystkie pozostałe dążą jako do celu ostatecznego, to, co przez przyzwoitość zwą darem łaski. (cyt. za: Curtius, 2009, s. 542)

Apogeum popularności toposu przypada na wiek XII (Hanusiewicz, 2004, s. 34). Z tego też okresu pochodzi bardzo znany traktat De amore Andreasa Capellanusa. Autor wyodrębnił cztery fazy miłości (Hanusiewicz, 2004, s. 18, 36; Hanusiewicz, 2012): danie nadziei, pocałunek, pieszczoty i pełne oddanie (Hanusiewicz, 2004, s. 36). Z kolei Mateusz z Vendôme wyróżnił aż sześć elementów. Jednak żaden z tych wzorów nie zagościł na stałe w literaturze i nie stał się toposem. Schemat kompozycyjny pentady miłosnej pozwalał organizować utwór, przedstawiając kolejne etapy zakochania. Nawet gdy jeden z elementów został pominięty, to interpretacja nie pozostawiała wątpliwości. Często łączono go z topiką pięciu zmysłów, która powstała później, bo we wczesnym średniowieczu, i obecna była także w sztuce (Nordenfalk, 1985, s. 1). Co więcej, liczba „5” ma także inne znaczące konotacje. U neopitagorejczyków była to liczba małżeńska - „3” oznacza mężczyznę, „2” kobietę. W aleksandryjskiej egzegezie „5” symbolizowało z kolei sensualizm i cielesność (Hanusiewicz, 2012).

$\mathrm{Na}$ obszarze kultury polskiej topos obecny jest w twórczości m.in. Andrzeja Krzyckiego (Ad amicam quinque lineae amoris, Cricii Carmina, 1888, s. 209). W Lekcyjach Kupidynowych Kaspra Twardowskiego pięć strzał Amora symbolizuje kolejne stopnie uwodzenia (Twardowski, 1997). Radosław Grześkowiak podkreśla, że ów topos pozwalał „zracjonalizować w poetyckim dyskursie tak nieuchwytne uczucie, jak miłość" (Grześkowiak, 1997, s. 8) i wykorzystywany był jako „konspekt opisu gry miłosnej” (Grześkowiak, 1997, s. 8). W romansach barokowych pentada miłosna występuje, choć czasem niektóre z jej elementów, zwłaszcza ostatni, zostają pominięte. Niedomówienia te pozwalają jednakże domyślać się, które to etapy zostały „niedookreślone”.

\footnotetext{
5 Na rozważania Friedmana powołuje się także Mirosława Hanusiewicz (zob. Hanusiewicz, 2004, s. 33).

6 „They consider these "points« to be of medieval origin and to have been four in number before scholastic refinement to five. Both notions are incorrect" (Friedman, 1965, s. 167).
} 
W romansach można wydzielić także „stopień zerowy”, gdyż zakochanie zaczyna rodzić się nie tylko przy bezpośrednim spotkaniu postaci, ale może kiełkować pod wpływem opowieści innych bohaterów. Adolf z romansu Drużbackiej adoruje boginię od pierwszego momentu, kiedy o niej usłyszał od Zefira. Jest pod takim wrażeniem, że nie może usnąć, ciągle o niej myśli. Prosi Zefira, aby ten nie przestawał o niej opowiadać. Orystella z Filomachiji zakochuje się w Alfonsie, choć zna go tylko z opowieści panien dworu. Słyszała od nich, że jest piękny i wspaniale śpiewa. Moment rodzenia się uczucia został przedstawiony następująco: „A w królewnie cichy się już żarzy / Ogień z pożądliwością i dziwne pragnienie” (Morsztyn, 2000a, s. 21). Po pierwszym spotkaniu z Alfonsem ma już ona „iskry w sercu cichego płomienia” (Morsztyn, 2000a, s. 22). Podobnie uczucie zaczyna kiełkować w Reblesie z utworu Potockiego: gdy ktoś chwali przy nim Tressę, ten coraz bardziej zakochuje się w dziewczynie: „Skąd, im ją każdy bardziej, kto tylko znał, chwalił, / Tym pułkownik gorętszą miłością się palił” (Potocki, 1924b, s. 156). Z kolei uczucie Włoszki ze Złocistej przyjaźniq zdrady rozpalała najpierw gra na lutni Polaka ${ }^{8}$. Włoszka słyszała tylko „instrument, do którego niepohamowany apetyt miała” (Korczyński, 2000, s. 39). W ten sposób zaczęła kiełkować w niej miłość. Następnie wysyła do niego swojego posłańca, aby wybadał, czy ten też darzy ją uczuciem. Polak początkowo wydaje się nie do zdobycia i nie odwzajemnia zalotów. Boi się, że romans może źle się dla niego skończyć, ale przystaje na wymianę korespondencji i pisze list do Włoszki, w którym żałuje, że wcześniej odrzucał jej zaloty.

Dostrzeżony w romansach „stopień zerowy” to etap „przedzmysłowy” - w wyobraźni bohatera tworzy się wyidealizowany obraz obiektu miłości (i pożądania). Gdy kochankowie - skonfrontowani z rzeczywistością - pierwszy raz się widzą, uczucie zostaje jeszcze bardziej umocnione.

Pierwszy stopień miłości to spojrzenie. Znany aforyzm Publiusza Syrusa (I w. p.n.e.) brzmi: Amor ut lacrima ab oculis oritur, in pectus cadit („miłość jest jak łza - powstaje w oczach, pada na serce"). Źródeł motywu uczucia rodzącego się poprzez wzrok należy szukać w starożytności, m.in. u Platona, Arystotelesa czy Plutarcha. W literaturze topos ów obecny jest w dawnym romansie greckim, eposie rzymskim, romansie średniowiecznym oraz renesansowym (Bohuszewicz, 2011b). Marsilio Ficino w Commentarium in convivium Platonis de amore uznaje wzrok za zmysł wyższy, gdyż służy poznaniu prawdy i piękna. Co więcej, ma realną siłę oddziaływania. Strzała Amora wnika przez oczy, a następnie zmierza ku sercu, „swej właściwej siedzibie” (Ficino, 1978, s. 284). To, że kluczem do miłości są oczy, zauważył także Łukasz Górnicki. W Dworzaninie polskim stwierdził (Górnicki, 1961, s. 347):

[...] oczy same, jako pewni od serca posłowie, siła sprawić mogą, bo nie tylko odkrywają myśli nasze, ale też częstokroć gwałtownemi promieńmi swemi przenikając przez drugie oczy, jako jasność przez szkło, do upodobanego serca, zagrzewają je i czynią je sposobne ku przyjęciu i rozżarzeniu miłości.

\footnotetext{
7 Miłość często łączona jest z ogniem, który rozpala żar namiętności. Motyw ten obecny był już w tradycji antycznej, sięgali po niego i rozwinęli go włoscy poeci dolce stil nuovo, do których należał m.in. Dante Alighieri (Skowera, 2012, s. 6). Metaforyka ta jest niezwykle bogata, charakteryzuje nie tylko romans barokowy, ale występuje również w innych gatunkach podejmujących tematykę miłosną (Maciejewska, 2009, s. 139-140).

8 Dobrochna Wężowicz-Ziółkowska grę na instrumencie zalicza do jednego z ośmiu kręgów tematycznych metaforyki w ludowej liryce miłosnej (Wężowicz-Ziółkowska, 1991, s. 150-160, tu s. 150).
} 
To właśnie autor Dworzanina spopularyzował ów motyw w rodzimej literaturze. Miłość w romansach barokowych to uczucie od pierwszego wejrzenia ${ }^{9}$. Ma się wrażenie, że czysto fizyczne, gdyż bohaterowie są przede wszystkim najpierw pod wrażeniem swojej nieprzeciętnej urody. Iwona Maciejewska podkreśla, że autorzy romansów nie przedstawiają dokładnie rodzącego się uczucia i nie uzasadniają go (Maciejewska, 2013, s. 33).

Fortuna zakochuje się w Adolfie od pierwszego wejrzenia, przede wszystkim jest pod wrażeniem jego urody. Wacław Borowy zauważa, że opis poznania się kochanków u d’Aulnoy (w przekładzie Raczyńskiego) jest spokojniejszy niż u Drużbackiej; Adolf wyznaje miłość, para podziwia nawzajem swoją urodę, z początku bogini jest oszołomiona (Borowy, 1920, s. 33). U rodzimej poetki odnajdujemy natomiast więcej emocji. Wywiązuje się małe zamieszanie, bogini nie jest zachwycona przybyszem, awantura łagodnieje dopiero po wygłoszeniu długiej mowy przez Adolfa. Boginię „powoli odstępują fochy”. Gdy Polak ze Złocistej przyjaźnia zdra$d y$ pierwszy raz widzi Włoszkę, także zaczyna w nim kiełkować uczucie: „Lub mu w sercu pochodnie Kupido zażegał, / Taił tych w sobie ogniów - nie rozumiał w rzeczy" (Korczyński, 2000, s. 40). W Historyi barzo pięknej Talez również zakochuje się od pierwszego wejrzenia w Perepodzie (Morsztyn, 2000b, s. 68-69):

\section{Na bankiecie ujźrzawszy królewnę pierwszego \\ Dnia, Talezy tak srogi zapał cielesnego \\ Poczuł w sobie płomienia, że k niej rozpalony \\ Nie mógł w sobie ugasić ognia z żadnej strony. \\ (w. 301-304)}

Moment uczucia rodzącego się dzięki spojrzeniu przyrównywany jest do ognia. Miłość pali kochanków od środka. Holefernes z utworu Potockiego zaczął darzyć Judytę gorącym uczuciem: „Który miłością spłonąwszy, z wielkiego / Ognia jak nigdy pił za wieku swego" (Potocki, 1924a, s. 145). Perepoda również zakochała się w Talezie, jak tylko go zobaczyła - „serduszko w niej skakało” (Morsztyn, 2000b, s. 70). Do pierwszego spotkania kochanków może dojść niespodziewanie. Galezyjus z romansu Morsztyna podczas przechadzki dostrzega w ogrodzie piękną pannę - Filidę, jest nią zachwycony: „stanął jako wryty” (Druga historyja, s. 273). Stwierdza, że nikogo piękniejszego nigdy nie spotkał. Natomiast Banialuka chce w sobie stłumić rodzące się uczucie do Królewicza, więc każe pannom śpiewać smutne pieśni. Początek miłości określany jest jako „iskierki”, z których powstaje ogień. Królewicz widzi, że Banialuka się w nim zakochała, i odwzajemnia to uczucie.

Tytułowy bohater romansu O Przemysławie i Cecylijej uważa, że z pomocą Bożą znajdzie najlepszą żonę ${ }^{10}$. Swój obraz przyszłego małżeństwa przedstawia następująco: „małżonkę i to-

9 Topos miłości od pierwszego wejrzenia występuje w Aitiach Kallimacha (w opowiadaniu o Akontiosie i Kydyppie). Uważa się, że stał się on inspiracją dla romansopisarzy greckich - Charitona i Ksenofonta z Efezu (zob. Polaszek, 1984, s. 131).

10 Rola Bożej woli w doborze małżonka jest charakterystyczna dla dydaktyki religijnej tekstów wczesnonowożytnych, pojawia się przykładowo w Komedyi Justyna i Konstancyjej Marcina Bielskiego (Bielski, 2001, s. 183-184): „Charitas mąż: Awo ja twoj, Panno, oblubieniec, / Chciej mi posłać swoj małżeński wieniec. / Pan Bog jest to małżeństwo sprawił, / Sama sie nama dziewosłębem zstawił. / Nie pacierzmi sobie-ś mię wypiała, / Ani woskiem na wodzie wylała. / Ale taka Boża wola była, / By ty ze mną w społeczności żyła”. Na temat rozważań dotyczących małżeństwa w Komedyi Justyna i Konstancyjej Bielskiego pisał m.in. Marcin Szyjkowski: „Tendencją utworu była propaganda małżeństwa" (Szyjkowski, 1936, s. 291; zob. też: Starnawski, 2001, s. 15-16). 
warzysza sobie znajdę takiego, z którym spokojne i miłe życie i zdrowie, i niebo mieć mogę" (Trzecia historyja, s. 281). Przemysław, jeżdżąc na polowania, zatrzymuje się w domku Teofila - ojca Cecylii. Dziewczyna podoba mu się, ceni on jej „dziarskość”, jednak nie ma w tym miłości; uczucie nie rodzi się od razu. Mimo to właśnie ją wybiera na swą przyszłą małżonkę, gdyż spodobało mu się jej dobre wychowanie i skromność. W romansie tym brak toposu miłości od pierwszego wejrzenia.

Kolejne etapy quinque amoris gradus są w romansach rzadsze, gdyż kochankowie najczęściej cierpią z powodu rozłąki, przeżywają przygody i pokonują trudności, aby na koniec odnaleźć się szczęśliwie. Zakochani w rozmowie posługują się „kodem miłości” w konwencji rozmowy dwornej, która podlega kontroli i nie jest wbrew pozorom egzaltacją uczuciową:

Ukochany posługuje się silnie skonwencjonalizowaną retoryką pochwały - piękna, cnoty czy mądrości ukochanej - która to pochwała, zgodnie z zasadą dźwigni panegirycznej, wywyższając przedmiot, jednocześnie poniża podmiot wypowiedzi. (Bohuszewicz, 2011a)

Rozmowa stawia mężczyznę w pozycji uległego względem ukochanej (Porębowicz, 1904, s. 511). Kochanek jest wasalem dominującej damy. Paweł Bohuszewicz zwraca uwagę na to, że rozmowa odsuwa moment „erotycznego spełnienia” (Bohuszewicz, 2011a). Denis de Rougemont nazwał to „miłością miłości” (Rougemont, 1999, s. 31). Bohaterowie romansów z reguły wywodzą się z arystokratycznych rodów, więc sposób ich wysławiania się zgodny jest ze statusem społecznym (Maciejewska, 2001, s. 75).

Kochankowie, aby pielęgnować swoje uczucie, spotykają się potajemnie. Miejsca schadzek są kameralne, zazwyczaj trudno dostępne i nieznane innym bohaterom. Jest to popularny w romansach topos locus horridus. Spotkaniom kochanków towarzyszy element niepewności i tajemniczości. W romansie Morsztyna Żałosny koniec miłości Zygismunda i Gwizdard widzą się w ukrytym lochu, do którego prowadzą tajne drzwi. Perepoda i Talez po kryjomu spotykają się w sadzie, do którego wchodzą tajemnym wejściem (Morsztyn, 2000b, s. 77):

Jest w sadzie dawna fortka, na wał więc tamtędy

chadzano ciasną ścieżką, a mury tam wszędy

puste stoją [...].

(w. 589-591)

Jest to miejsce tajemnicze, opuszczone, zapomniane, dla nikogo innego niedostępne, co czyni je intymnym. W utworze Korczyńskiego Polak z Włoszką spotykają się i rozmawiają w sekretnym przejściu między ich domami. W miejscu tym widywał się wcześniej z ukochaną dziadek Włoszki.

Namiastką spotkań, wymiany myśli czy rozmowy są prezenty. Kochankowie przekazują sobie podarunki. Przykładowo, królewicz wspomina Banialukę, gdy patrzy na połowę pierścienia, który od niej otrzymał: „Wspomniał pieszczonej ręki całowanie” (Morsztyn, 2007, s. 53). Pierścień kochanków jest znakiem ich miłości.

Kochankowie często muszą ukrywać swoje uczucie przed innymi. Wtedy, gdy spotykają się przy świadkach, porozumiewają się za pomocą spojrzeń, zawstydzają się, szepczą do 
siebie. Łączącego uczucia jednak nie da się ukryć, postronni widzą drżenie rąk. Tak jest w przypadku Talezusa i Perepody podczas bankietu. Także bohaterowie Banialuki chcą zachować miłość w tajemnicy.

Trzecim stopniem miłości jest dotyk. Marsilio Ficino w komentarzu do filozofii Platona umieszczał go wśród niższych, gorszych zmysłów (obok powonienia i smaku). Uważał, że czyni on człowieka podobnym do zwierząt (Hanusiewicz, 2004, s. 120-121). W tradycji arystotelesowskiej dotyk nie był tak deprecjonowany. Uznawano go za pierwszy zmysł „warunkujący samo istnienie” (Hanusiewicz, 2004, s. 121). Sam Arystoteles łączył ów zmysł z pożądaniem (Hanusiewicz, 2004, s. 123).

Subtelny dotyk zajmuje miejsce na marginesie historii miłosnych. Przyczyn należy upatrywać, podobnie jak w przypadku rozmowy, w częstej rozłące kochanków. W romansach dotyk stanowić może substytut coitus (podobnie jak pocałunek), często ma podtekst erotyczny. Ojciec Orystelli wyraził zgodę na to, aby Alfons jej pilnował i usługiwał. Młodzi, korzystając z okazji, że są sami, zbliżają się do siebie, ukradkiem się przy tym całując, tak więc oba stopnie (dotyk i pocałunek) mogą występować równocześnie. Talezy opiekuje się Perepodą podczas podróży statkiem, czule ją obejmuje, przytula i „całuje serdecznie”. Oczywiście do największego „nasycenia" dotykiem dochodzi podczas ostatniego gradus amoris. Czasem w hierarchii stopni miłości dotyk poprzedza ostatni akt spełnienia, występując po pocałunku. Nie zawsze jednak jest wyczekiwany przez kobietę. W utworze Potockiego Gazela dość szybko zauważa, że Dampier się nią interesuje: „albo uskubnął, albo ją pomacał” (Potocki, 1924b, s. 188) - jednak jest to dalekie od subtelności. Gazeli nie podobają się te zaloty.

Czwartym stopniem jest pocałunek, którego literackie źródła opisu sięgają poezji antycznej i Biblii. W poezji antycznej symbolizował wymianę dusz (Katullus), zaś z Pieśni nad Pieśniami wywodzi się motyw słodyczy ust kochanki (Hanusiewicz-Lavalle, 2011). W twórczości związanej z kulturą polską pierwsze opisy pocałunków znalazły się w utworach nowołacinników (obok wspomnianego Krzyckiego także np., wcześniej, u Kallimacha i Celtisa), którzy korzystali z metafory wymiany dusz kochanków podczas osculum (Hanusiewicz, 2004, s. 93).

Zaskoczeniem może być fakt, że romanse nie obfitowały w kwieciste opisy gorących pocałunków. Pojawiają się one przy okazji innych scen. Nie są eksponowane przez autorów, choć niewątpliwie mają podtekst erotyczny, a nie mistyczny. Gdy Orystella odwiedza Alfonsa w więzieniu i zaczynają się całować, zostaje nazwana „pijaweczką”. Jest to tylko wstęp do coitus. Kochankowie obdarowują się pocałunkami nie tylko w usta - Alfons całuje Orystellę w nóżkę (Morsztyn, 2000a, s. 26):

W nóżkę ją, pierzyneczki trochę uchyliwszy, całował, ba, i w rączkę ukradkiem, gdy chciała, aż mu po tym i ustek sama nadstawiała.

(w. 256-258)

Iwona Maciejewska podkreśla, że polskie romanse nie zawierają „ciekawych artystycznie obrazów pocałunków kochanków" (Maciejewska, 2013, s. 38). Przyczyn można upatrywać w tym, że poeci starali się, aby ich utwory pełniły funkcję docere, stąd też stronili od opisów gorących uniesień. 
W romansach rzadko też zostaje przedstawiony opis zbliżenia kochanków. Narrator często unika przedstawiania sceny dosłownie, w związku z czym wiele tu niedopowiedzeń, metafor ${ }^{11}$. Jan Ziolkowski wspomina, że o niemożności bezpośredniego opisu aktu miłosnego pisał już Kwintylian ${ }^{12}$. Witold Wojtowicz zwraca uwagę na istnienie wręcz pewnego rodzaju tabu językowego w chrześcijańskiej Europie (Wojtowicz, 2012, s. 205) ${ }^{13}$. Narracyjne przedstawienie zbliżenia między kobietą i mężczyzną praktycznie nie występowało, zastępowano je abstrakcyjnymi opisami ${ }^{14}$. W Wizerunku złocistej przyjaźnią zdrady dochodzi w końcu do aktu miłosnego, ale nic nie jest powiedziane wprost, stosunek ujęty został poetycko i przedstawiony jako zabawa kotka i myszki (Korczyński, 2000, s. 144):

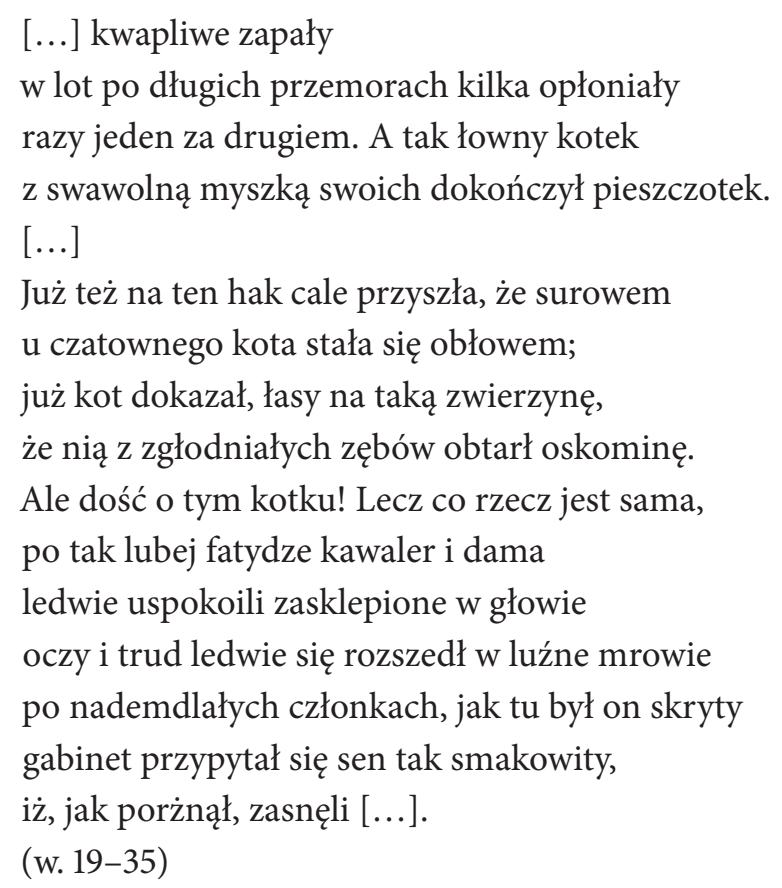

Uniesienie jest silne, gdyż oboje, jak zostało to w romansie zaznaczone, długo „pościli”. Kochankowie rozkoszom oddają się kilkakrotnie. Nic nie zostaje przedstawione dosłownie, narrator korzysta z metafor i symboli, eufemizmów i omówień. Marek Prejs zauważa, że „artyści rokoka uczynili z miłości rodzaj eleganckiej zabawy, starając się, aby nawet gra zmysłów stała się czymś w rodzaju uszlachetnionej sztuki” (Prejs, 1989, s. 295). W kolejnym fragmencie zbliżenie sugerowane jest

\footnotetext{
11 Iwona Maciejewska, omawiając scenę zbliżenia w Historii Ormunda z Libeiną, podkreśla, że „zadziałał [...] rodzaj autocenzury, który kazał narratorowi w zawoalowany sposób opowiedzieć o intymnym zbliżeniu, nazywanym "politowaniem «" (Maciejewska, 2013, s. 37).

$12,[. .$.$] he [Kwintylian - J.W.-T.] leaves the impression that the only truly unmentionable acts and organs are sexual”$ (Ziolkowski, 1998, s. 43).

13 Badacz podkreśla również, że „właściwości językowe dworności czy przystojności są pochodną ideałów językowego decorum sformułowanego przez Cycerona, Kwintyliana czy Senekę" (Wojtowicz, 2012, s. 204; zob. też: Wojtowicz, 2002, s. 88).

14 „Według Wolfganga-Dietera Stempla z jego Mittelalterliche Obszönität als literarästhetisches Problem bezpośrednie nazywanie naturalia et pudenda w prymarnie dworskich gatunkach praktycznie nie występuje, skatologia zaś jest $\mathrm{w}$ nich całkowicie nieobecna, natomiast abstrakcyjne i opisowe wyrażenia idą daleko, budując odpowiedniki przedstawianego w detalach aktu płciowego" (Wojtowicz, 2012, s. 204).
} 
następująco: „Pobrawszy się za ręce, poszli do komory / Wenerze tam zwyczajne oddawać ofiary” (Korczyński, 2000, s. 151). Tradycja erotycznej metaforyki pozostaje „aktywna” także w rokoku. Zdaniem Maciejewskiej to właśnie przede wszystkim erotyczne pożądanie jest głównym motywem działań bohaterów, a nie prawdziwa miłość (Maciejewska, 2013, s. 43). Przy czym, co podkreśla badaczka, sympatią narrator darzy kochanków, a nie męża „rogacza” (Maciejewska, 2001, s. 123126) ${ }^{15}$. Znacznie śmielej akt miłosny w romansach szkicuje Hieronim Morsztyn. Opis stosunku został przedstawiony w Alfonsie i Orystelli. Jest to pierwsze zbliżenie tej pary (Morsztyn, 2000a, s. 27):

Po trzykroć z sobą miłość tę zawrzeć kusili wtenczas, a ledwie czwartym razem dokończyli. Już stojąc, już i leżąc, aż w dziewiątym gmachu tam dopiero dokazał, czego chciał, z przestrachu: młode lata panieńskie i wstyd przyrodzony, boleść i strach obojga, więc zaś z drugiej strony skwapliwość przeszkadzała do skutku miłości, do którego oboje z cielesnej chciwości wyprzedzali; atoli Wenus dokazała, że w tej rzeczy był koniec i sprawę wygrała. Orystella, giezłeczko one pokrwawione schowawszy, wdziała drugie, zdrady popełnione twardym snem pokrywając.

(w. 273-285)

Opis zaskakuje dosadnością i szczegółami. W żadnym z innych romansów nie spotkamy się na przykład z informacjami o krwi. Następnego dnia Orystella źle się czuje. Kolejne zbliżenie kochanków już nie zostało przez poetę tak dokładnie opisane: „figiel odprawował / raz, dwa, trzy" (Morsztyn, 2000a, s. 29). Z kolei Zygismunda jest trzymana w domu ojca, który nie chce, żeby wyszła za mąż, co stało się dla niej wielką udręką. Szczególnie mocno doskwiera jej pożądanie cielesne. W utworze zostają dokładnie opisane przeżycia i przemyślenia bohaterki. Kobieta wstydzi się rozmawiać o tym z ojcem, więc w tajemnicy postanawia się z kimś spotykać, aby dać upust swoim żądzom (Morsztyn, 2000c, s. 42):

Tę gorączkę ta pani znacznie czując w sobie, przemyśliwała, jakby zabiec tej chorobie, bo jej o to wstyd ojca nie dopuścił prosić, aby ją wydał za mąż, a płomienia znosić nie mogła cichych iskier ognia cielesnego i jęła myślić o tym, jako by do tego przyść mogła, żeby się z kim grzecznym namówiła, a po kryjomie żądzy swojej dogodziła.

(w. 33-40)

15 Pomysł Korczyński zaczerpnął z Historii o siedmiu mędrcach Poncjana, z tym że utwór rodzimego poety jest zdecydowanie bardziej nasycony erotyzmem niż pierwowzór (Maciejewska, 1992, s. 19-20; Maciejewska, 2013, s. 43). 
Ta potrzeba staje się impulsem do poszukiwania kochanka. I tak Zygismunda rozkochuje się w Gwizdardzie, który służy na dworze jej ojca. Gdy po raz pierwszy się spotykają sam na sam, kobieta od razu zaczyna całować kochanka. Opis tej chwili jest dosadny, zniżający zachowanie Zygismundy do zwierzęcych instynktów (Morsztyn, 2000c, s. 44):

Tam znalazszy, Gwizdarda chciwie obłapiała, a usty go we wszytkie członki całowała, lgnąc nań jako ptak na lep albo gdy z tesknice koło samców gruchają jurne gołębice.

(w. 107-110)

Miłość zostaje sprowadzona do pożądania fizycznego ${ }^{16}$. Oddanie się miłosnym uniesieniom w przypadku Zygismundy i Gwizdarda zostaje przez narratora tylko wspomniane bez podawania szczegółów: „Wszedszy z sobą na pokój, zabawek miłości / W namiotku zażywali i spólnych radości” (Morsztyn, 2000c, s. 44). Przedstawienie cielesnych uniesień obecne jest w utworach Morsztyna i Korczyńskiego. Romanse tych autorów poniekąd odkrywają seksualność kobiety. Najpełniejszą realizację quinque gradus amoris podejmuje w romansach Hieronim Morsztyn. Poeta poprzez losy swoich bohaterów, którzy kończą tragicznie, neguje ideał miłości neoplatońskiej i tradycji petrarkistowskiej (Stępień, 1996, s. 11). U Morsztyna natura ludzka jest skonfliktowana, miłość zostaje zrównana z żądzą i ten, kto jej ulega, sprowadza na siebie nieszczęście, z którego wyzwolić może go tylko śmierć rozumiana dosłownie lub jako zwieńczenie aktu miłosnego. Paweł Stępień wprost stwierdza, że poezję Morsztyna zdominował „obsesyjny erotyzm” (Stępień, 1996, s. 11).

Paweł Bohuszewicz podkreśla, że w romansie barokowym miłość traktowana jest jako niepodlegający wpływom czasu aspekt życia bohaterów. Po prostu istnieje i nie rozwija się wraz z ciągiem fabuły, jak będzie w powieści nowoczesnej (Bohuszewicz, 2009, s. 82). O takim właśnie sposobie kreacji pisze Michaił Bachtin:

Miłość bohaterów jest od początku niewątpliwa i pozostaje absolutnie niezmienna w ciągu całej powieści, zachowana zostaje także niewinność bohaterów, końcowe małżeństwo łączy się bezpośrednio z miłością, która związała bohaterów, gdy spotkali się po raz pierwszy na początku powieści. (Bachtin, 1982, s. 284)

I tak dzieje się w zdecydowanej większości romansów barokowych - bohaterowie zakochani są w sobie od początku i uczucie z biegiem zdarzeń nie zmienia się.

W utworach topos pięciu stopni miłości stał się istotnym elementem narracji romansowej dopełniającym obraz osoby zakochanej. W niektórych tekstach odnaleźć można etap „zerowy” - kochanko-

\footnotetext{
16 O pożądaniu, które warunkuje działanie bohaterów romansów Morsztyna, pisała Aleksandra Mucha: „Żądza jest zdolna determinować życie człowieka, każdy podlega jej władzy. Podkreśleniu potęgi żądzy służy symboliczne określenie jej metaforą ognia, a jej siła stawiana jest ponad lękiem przed utratą życia. W naturze człowieka tkwi bardzo silna pokusa, której trudno sprostać. Poeta dramatyzuje konflikt zmysłowości i religijności udowadniając, że człowiek nie jest zdolny wyzwolić się od swoich potrzeb cielesnych. Orystella wyraża nawet pogląd, że tylko śmierć może uwolnić od porywów namiętności” (Mucha, 2008, s. 56). Należy przy tym podkreślić, że „śmierć” można odczytywać jako metonimię szczytowania zarówno kobiety, jak i mężczyzny.
} 
wie zakochują się, słuchając opowieści o późniejszym obiekcie miłości. W związku z częstą pielęgnacją uczucia „na odległość” w romansach nie ma rozbudowanych etapów rozmowy, dotyku i pocałunku. Ze względu na tabu językowe często pomijany jest ostatni etap - spełnienie fizyczne. Niewiele tu opisów subtelnych zbliżeń. Jest to spowodowane tym, że protagoniści po pierwszym zachwycie i zakochaniu się od pierwszego wejrzenia z powodu zawirowań losu zostają na długo rozdzieleni.

\section{Bibliografia podmiotowa}

Bielski, M. (2001). Komedyja Justyna i Konstancyjej. M. i J. Bielscy. Sejm niewieści. Oprac., kom. i wprow. J. Starnawski, sł. wstępnym poprz. A. Gorzkowski. Kraków: Księgarnia Akademicka.

Andreae Cricii Carmina (1888). Edidit Casimirus Morawski. Cracoviae: Universitas Jagiellonicae.

Druga historyja. O Galezyjusie, synu Demokryta, i Filidzie, córce Arystydesa, szlachty cypryjskiego króla (2007). W: H. Morsztyn, Historyja ucieszna o królewnie Banialuce (s. 272-278). Wyd. R. Grześkowiak, Warszawa: Instytut Badań Literackich (= Druga historyja).

Drużbacka, E. (2002). Fabuła o książeciu Adolfie dziedzicu Roksolanii, którego Czas, przez lat trzysta szukając, znaleźć nie mógł. Przypadkiem powracając z wyspy szczęśliwości, od tegoż Czasu złapany, śmierci prawu zadosyć uczynić musiał, które dla wszystkich najdłużej żyjących ludzi postanowione. W: E. Drużbacka, Wybór poezji (s. 101-165). Oprac. J. Niedźwiedź. Kraków: Universitas.

Ficino, M. (1978). Commentaire sur le Banquet de Platon. Trad. M. Raymond. Paris. Cyt. i tłum. za: Hanusiewicz, 2004.

Górnicki, Ł. (1961). Dworzanin polski. W: Ł. Górnicki, Pisma. T. 1. Oprac. R. Pollak. Warszawa: Państwowy Instytut Wydawniczy.

Korczyński, A. (2000). Wizerunk złocistej przyjaźniq zdrady. Wyd. R. Grześkowiak. Warszawa: Instytut Badań Literackich.

Morsztyn, H. (2000a). Alfonsa, książęcia ateńskiego, i Orystelle, królewny kreteńskiej, miłość śmiercią okrutną zapieczętowana. W: H. Morsztyn, Filomachija (s. 19-40). Wyd. R. Grześkowiak. Warszawa: Instytut Badań Literackich.

Morsztyn, H. (2000b). Historyja barzo piękna o Talezie, królewicu lidyjskim, a o Perepodzie, królewnie aragońskiej. W: H. Morsztyn, Filomachija (s. 59-106). Wyd. R. Grześkowiak. Warszawa: Instytut Badań Literackich.

Morsztyn, H. (2000c). Żałosny koniec miłości niezbednej dwojga ludzi w sobie się kochających. W: H. Morsztyn, Filomachija (s. 41-58). Wyd. R. Grześkowiak. Warszawa: Instytut Badań Literackich.

Morsztyn, H. (2007). Historyja ucieszna o zacnej królewnie Banialuce ze wschodniej krainy. W: H. Morsztyn, Historyja ucieszna o królewnie Banialuce (s. 35-135). Wyd. R. Grześkowiak. Warszawa: Instytut Badań Literackich.

Potocki, W. (1924a). Judyta. W: W. Potocki, Wiersze wybrane (s. 133-148). Wyd. i objaśnił A. Brückner. Kraków: Biblioteka Narodowa.

Potocki, W. (1924b). Historyja równej odwagi, ale różnej fortuny dwu pięknych Tressy i Gazele w Holandyjej panien. W: W. Potocki, Wiersze wybrane (s. 149-198). Wyd. i objaśnił A. Brückner. Kraków: Biblioteka Narodowa.

Trzecia historyja. O Przemysławie, książęciu oświęcimskim, i o Cecylijej, małżonki jego, dziwnej stateczności (2007). W: H. Morsztyn, Historyja ucieszna o królewnie Banialuce (s. 278-289). Wyd. R. Grześkowiak. Warszawa: Instytut Badań Literackich (= Trzecia historyja).

Twardowski, K. (1997). Lekcyje Kupidynowe. Wyd. R. Grześkowiak. Warszawa: Instytut Badań Literackich. 


\section{Bibliografia przedmiotowa}

Bachtin, M. (1982). Formy czasu i czasoprzestrzeni w powieści. W: M. Bachtin, Problemy literatury i estetyki. Przeł. W. Grajewski. Warszawa: Czytelnik.

Bohuszewicz, P. (2009). Gramatyka romansu. Polski romans barokowy w perspektywie narratologicznej. Toruń: Wydawnictwo Naukowe Uniwersytetu Mikołaja Kopernika.

Bohuszewicz, P. (2011a). Rozmowa dworna (barokowy romans miłosno-przygodowy). Pobrane z: http://sensualnosc.ibl.waw.pl (15.01.2016).

Bohuszewicz, P. (2011b). Wzrok (romans miłosno-przygodowy polskiego baroku). Pobrane z: http://sensualnosc.ibl.waw.pl (13.03.2016).

Borowy, W. (1920). Drużbacka i pani d’Aulnoy („Fabuła o Xiążęciu Adolfie”). Pamiętnik Literacki, 17-18 (1-4), $17-37$.

Curtius, E.R. (2009). Literatura europejska i łacińskie średniowiecze. Tłum. A. Borowski, Kraków: Universitas.

Friedman, L.J. (1965). Gradus amoris. Romance Philology, 19, 167-177.

Grześkowiak, R. (1997). Wprowadzenie do lektury. W: K. Twardowski, Lekcyje Kupidynowe (s. 5-15). Wyd. R. Grześkowiak. Warszawa: Instytut Badań Literackich.

Hanusiewicz, M. (2004). Pięć stopni miłości. O wyobraźni erotycznej w polskiej poezji barokowej. Warszawa: Wydawnictwo Naukowe Semper.

Hanusiewicz, M. (2012). Pięć stopni mitości w literaturze staropolskiej. Pobrane z: http://sensualnosc.ibl.waw. $\mathrm{pl}(13.03 .2016)$.

Hanusiewicz-Lavalle, M. (2011). Pocałunek w literaturze staropolskiej. Pobrane z: http://sensualnosc.ibl.waw. $\mathrm{pl}(15.12 .2015)$.

Kruszewska, T. (1960). Stan badań i problematyka studiów nad romansem polskim XVII wieku. Ze Skarbca Kultury, 12 (1), 31-72.

Maciejewska, I. (1994). Ukształtowanie narratora i narracji w „Złocistej przyjaźnią zdradzie” Adama Korczyńskiego. Klucz do lektury utworu. W: D. Ossowska (red.), Teksty. Konteksty. Interpretacje. Olsztyn: Wydawnictwo Wyższej Szkoły Pedagogicznej.

Maciejewska, I. (2001). Narracja w polskim romansie barokowym. Olsztyn: Wydawnictwo Uniwersytetu Warmińsko-Mazurskiego.

Maciejewska, I. (2009). Wyrazić niewyrażalne - język miłości w „Rozmowach listownych” Wojciecha Stanisława Chrościńskiego. Prace Językoznawcze, 11, 135-146.

Maciejewska, I. (2013). Miłość i erotyzm w piśmiennictwie czasów saskich. Olsztyn: Wydawnictwo Uniwersytetu Warmińsko-Mazurskiego.

Michałowska, T. (1972). Romans XVII i pierwszej połowy XVIII wieku w Polsce. Analiza struktury gatunkowej. W: J. Pelc (red.), Problemy literatury staropolskiej. Wrocław: Zakład Narodowy im. Ossolińskich.

Miszalska, J. (2003). „Kolloander wierny” i „Piękna Dianea”. Polskie przekłady włoskich romansów barokowych. Kraków: Universitas.

Mucha, A. (2008). Między erotyką a świętością (w poezji Kaspra Twardowskiego i Hieronima Morsztyna). Slavica Litteraria, 11 (1), 53-62.

Nordenfalk, C. (1985). The five senses in late Medieval and Renaissance art. Journal of the Warburg and Courtauld Institutes, 48, 11-22.

Polaszek, E. (1984). Sztuka portretowania postaci w romansie greckim. Wrocław: Zakład Narodowy im. Ossolińskich.

Porębowicz, E. (1904). Teoria średniowieczna „miłości dwornej”. Pamiętnik Literacki, 3 (1-4), 505-541. 
Prejs, M. (1998). Poezja późnego baroku: główne kierunki przemian. Warszawa: Państwowe Wydawnictwo Naukowe.

Rougemont, D. De (1999). Miłość a świat kultury zachodniej. Tłum. L. Eustachiewicz. Warszawa: Pax.

Skowera, M. (2012). Śmiertelna rozkosz. Motywy ognia i wody oraz ich rola w opisie choroby miłosnej w „Roksolankach” Szymona Zimorowica oraz cyklu erotyków przypisywanych Mikołajowi Sępowi Szarzyńskiemu. Konteksty Kultury, 9, 5-12.

Starnawski, J. (2001). Wprowadzenie. W: M. Bielski, Komedyja Justyna i Konstancyjej. M. i J. Bielscy, Sejm niewieści. Oprac., kom., i wprow. J. Starnawski, sł. wstępnym poprz. A. Gorzkowski. Kraków: Księgarnia Akademicka.

Stępień, P. (1996). Poeta barokowy wobec przemijania i śmierci. Hieronim Morsztyn - Szymon Zimorowic Jan Andrzej Morsztyn. Warszawa: Wydawnictwo DiG.

Szyjkowski, M. (1936). Dramat w Polsce. W: Dzieje literatury pięknej w Polsce. Praca zbiorowa. T. 2. Kraków: Polska Akademia Nauk.

Wężowicz-Ziółkowska, D. (1991). Miłość ludowa. Wzory miłości wieśniaczej w polskiej pieśni ludowej XVIIIXIX wieku. Wrocław: Polskie Towarzystwo Ludoznawcze.

Wojtowicz, W. (2002). Szkice o poezji obscenicznej i satyrycznej Andrzeja Krzyckiego. Szczecin: Wydawnictwo Naukowe Uniwersytetu Szczecińskiego.

Wojtowicz, W. (2012). Między literatura a kulturą. Studia o „literaturze mieszczańskiej” przełomu XVI i XVII wieku. Szczecin: Wydawnictwo Naukowe Uniwersytetu Szczecińskiego.

Ziolkowski, J.M. (1998). Obscenity in the Latin Grammatical and Rhetorical Tradition. W: Obscenity: Social Control and Artistic Creation in the European Middle Ages. Cultures, Beliefs and Traditions (s. 41-59). Edit. J.M. Ziolkowski. Leiden: Brill.

\section{The Topos quinque gradus amoris in Polish Baroque romances}

Summary:

Formation of topoi quinque gradus amoris in the polish Baroque romances is discussed in this article. Love is the most important emotion between the protagonists and it has a major influence on the romance's plot. The article is focused on five stages of love: look, conversation, touch, kiss and coitus. This article refers to texts written by: Hieronim Morsztyn, Wacław Potocki, Adam Korczyński and Elżbieta Drużbacka.

Słowa kluczowe: romans barokowy, topos, miłość, pięć stopni miłości

Keywords: baroque romance, topos, love, quinque gradus amoris (five stages of love) 